\title{
Health impacts of female genital mutilation/cutting: A synthesis of the evidence
}

\author{
Samuel Kimani \\ Jacinta Muteshi-Strachan \\ Population Council \\ Carolyne Njue \\ Population Council
}

Follow this and additional works at: https://knowledgecommons.popcouncil.org/departments_sbsr-rh

Part of the Demography, Population, and Ecology Commons, Family, Life Course, and Society Commons, International Public Health Commons, Maternal and Child Health Commons, Sociology of Culture Commons, and the Women's Health Commons How does access to this work benefit you? Let us know!

\section{Recommended Citation}

Kimani, Samuel, Jacinta Muteshi-Strachan, and Carolyne Njue. 2016. "Health impacts of female genital mutilation/cutting: A synthesis of the evidence," Evidence to End FGM/C Programme: Research to Help Girls and Women Thrive. New York: Population Council. 


\section{Evidence to End FGM/C}

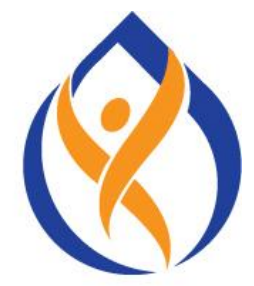

Research to Help Girls and Women Thrive

\section{HEALTH IMPACTS OF FEMALE GENITAL MUTILATION/CUTTING: A SYNTHESIS OF THE EVIDENCE}
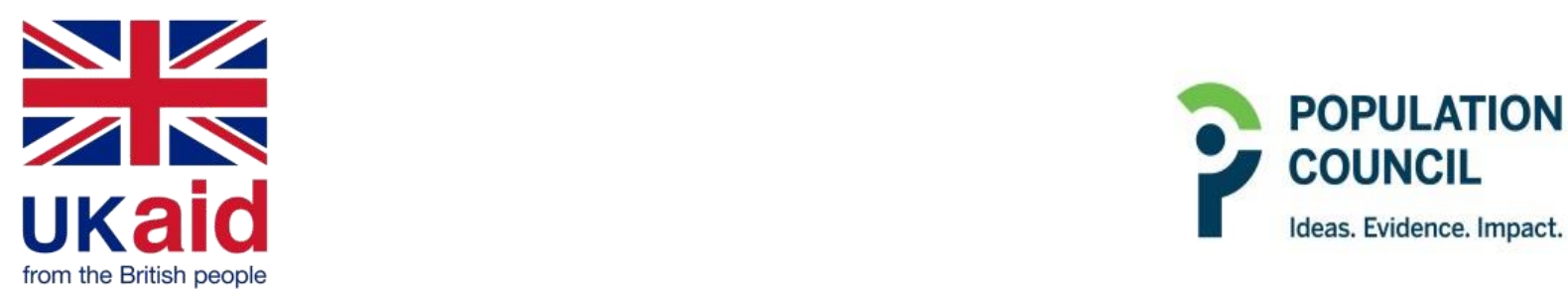


\section{HEALTH IMPACTS OF FGM/C: A SYNTHESIS OF THE EVIDENCE OCTOBER 2016}


Evidence to End FGM/C: Research to Help Girls and Women Thrive generates evidence to inform and influence investments, policies, and programs for ending female genital mutilation/cutting in different contexts. Evidence to End FGM/C is led by the Population Council, Nairobi, in partnership with the Africa Coordinating Centre for the Abandonment of Female Genital Mutilation/Cutting (ACCAF), Kenya; Gender and Reproductive Health \& Rights Resource Center (GRACE), Sudan; Global Research and Advocacy Group (GRAG), Senegal; Population Council, Nigeria; Population Council, Egypt; Population Council, Ethiopia; MannionDaniels, Ltd. (MD); Population Reference Bureau (PRB); University of California, San Diego (Dr. Gerry Mackie); and University of Washington, Seattle (Prof. Bettina Shell-Duncan).

POPULATION COUNCIL

Ideas. Evidence. Impact.
The Population Council confronts critical health and development issues, from stopping the spread of HIV to improving reproductive health and ensuring that young people lead full and productive lives. Through biomedical, social science, and public health research in 50 countries, we work with our partners to deliver solutions that lead to more effective policies, programs, and technologies that improve lives around the world. Established in 1952 and headquartered in New York, the Council is a nongovernmental, non-profit organization governed by an international board of trustees. www.popcouncil.org

ACCAF is based at the University of Nairobi, College of Health Sciences, a premier institution for training of health care professionals, and a leader in health research and community services. Our goals and objectives are to: strengthen capacity for FGM/C research in Africa, implement FGM/C interventions, and improve care for women and girls who have undergone $\mathrm{FGM} / \mathrm{C}$, monitor progress in the abandonment of FGM/C, and inform policy programming on FGM/C issues.

Suggested citation: Kimani Samuel, Jacinta Muteshi and Carolyne Njue. October, 2016. Health Impacts of FGM/C: A Synthesis of the Evidence," Evidence to End FGM/C Programme: Research to Help Girls and Women Thrive. New York: Population Council. http://www.popcouncil.org/EvidencetoEndFGM-C

Please address any inquiries about the Evidence to End FGM/C programme consortium to: Dr. Jacinta Muteshi, Project Director, jmuteshi@popcouncil.org

(c) 2016 The Population Council, Inc.

Funded by:

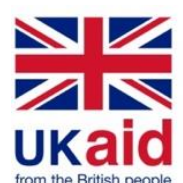

This document is an output from a project funded by UK aid by the UK Government for the benefit of developing countries. However, the views expressed and information contained in it are not necessarily those of, or endorsed by, the UK Government, which can accept no responsibility for such views or information or for any reliance placed on them. 


\section{Acknowledgments}

This report was authored by Dr. Samuel Kimani, senior lecturer at the School of Nursing and a researcher at the Africa Coordinating Centre for the Abandonment of Female Genital

Mutilation/Cutting (ACCAF), University of Nairobi; and Jacinta Muteshi, Programme Director, and Carolyne Njue, Senior Technical Advisor, at Evidence to End FGM/C: Research to Help Girls and Women Thrive, Population Council. The authors of this report are grateful for the insightful review and comments by Prof. Guyo Waqo Jaldesa and Prof. Joseph Karanja of the ACCAF team; and John Townsend, Charlotte Warren, Wilson Liambila, and Charity Ndwiga of the Population Council. Special thanks to other reviewers: Ian Askew, director, Department of Reproductive Health and Research at the World Health Organization (formerly of the Population Council) and expert reviewers at DFID; R. Elise B. Johansen of the Norwegian Center for Violence and Traumatic Stress Studies in Oslo, Norway; and Christina Catherine Pallitto and Lale Say, both of the World Health Organization. The authors also appreciate the editorial support of Carol Gachiengo.

(c) 2016 The Population Council, Inc. All rights reserved. 


\section{TABLE OF CONTENTS}

Acknowledgments ..............................................................................................................ii

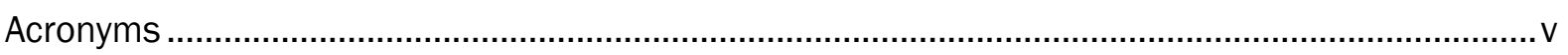

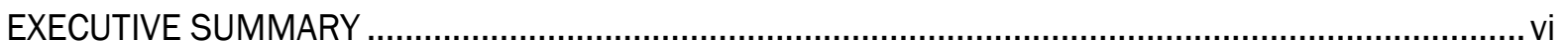

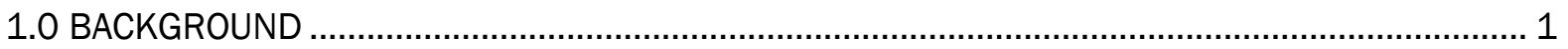

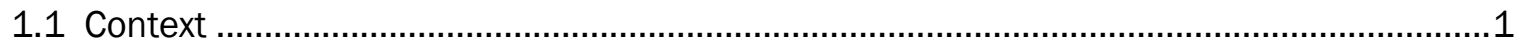

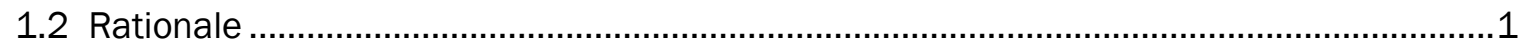

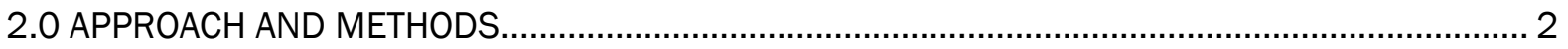

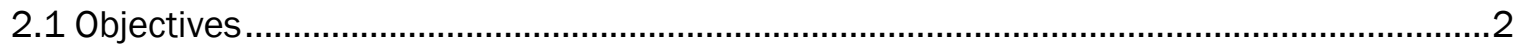

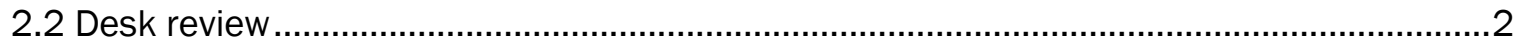

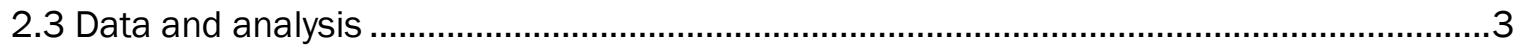

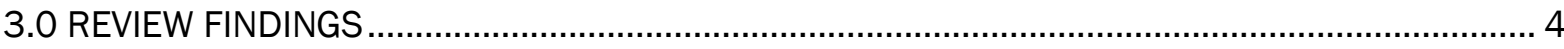

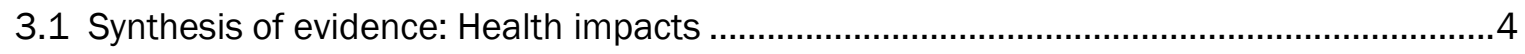

3.2 Synthesis of evidence: Curative and preventive interventions recommended for health

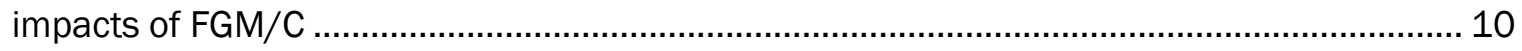

3.3 Improvements to enhance pre-service training for frontline health care providers .......... 14

Conclusion

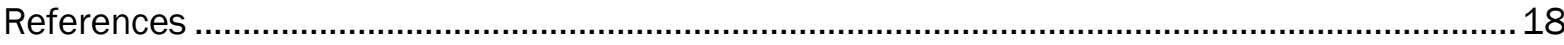




\section{ACRONYMS}

ACCAF

DFID

FGM/C

FIGO

GRACE

GRAG

HIV

HIV/AIDS

MD

$\mathrm{MeSH}$

(NS)

PPH

PRB

(S)

STDs

WHO
Africa Coordinating Centre for the Abandonment of Female Genital Mutilation/Cutting

Department for International Development

Female genital mutilation/cutting

International Federation of Gynecology and Obstetrics

Gender and Reproductive Health \& Rights Resource Center

Global Research and Advocacy Group

Human immunodeficiency virus

Human immunodeficiency virus/Acquired immune deficiency syndrome

MannionDaniels, Ltd.

Medical Subject Headings

Not statistically significant

Postpartum haemorrhage

Population Reference Bureau

Statistically significant

Sexually transmitted diseases

World Health Organization 


\section{EXECUTIVE SUMMARY}

Female genital mutilation/cutting (FGM/C) continues to be a threat to women's and girls' health and human rights globally. A sizeable body of evidence has developed over the past three decades on the direct health impacts of FGM/C. However, the evidence has been spread out and detached in diverse research, interventional, and training materials, making it cumbersome for quick reference when responding to women and girls exposed to the health effects of $\mathrm{FGM} / \mathrm{C}$. The Africa Coordinating Centre for the Abandonment of Female Genital Mutilation/Cutting (ACCAF), with support from the Population Council, sought to synthesize the evidence on the health impacts of FGM/C, identify recommended interventions, and compile and analyse the existing reference materials.

The goal of the review was to inform the development of a comprehensive set of training guidelines and materials for frontline health care providers so they can manage the care of women and girls who have undergone FGM/C, prevent the practice at the community level, and accelerate abandonment of FGM/C practices. An analysis of existing systematic reviews, metaanalyses, and published studies on health impacts associated with FGM/C and their specific interventions was conducted. A content analysis of 44 reference materials related to FGM/C was conducted using an updated data abstraction form that included 17 review criteria. Descriptive statistics were applied to the generated data to understand the components of the analysed documents. A review and validation of the outcomes and interventions were carried out by medical experts on the ACCAF team.

The health impacts associated with $\mathrm{FGM} / \mathrm{C}$ that require interventions have been broadly categorised into: immediate, genito-urinary, gynecological, obstetric, sexual and psycho-social consequences. An analysis of existing training and research reference materials on FGM/C management showed major strength in epidemiology, but scored marginally on physical, gynecological, and obstetric complications. In addition, the reference materials scored poorly on the sexual and psycho-social impacts of FGM/C. Curative and preventive interventional approaches are recommended in the review for the various health consequences. Specifically, capacity building for health care providers to respond to women exposed to FGM/C in both health care facility and community settings should be prioritized. In addition, strengthening the health care systems by anchoring $\mathrm{FGM} / \mathrm{C}$ interventions to existing programs and socio-community structures, especially in high prevalence areas, and by establishing supervisory mechanisms, protocols, documentation, and referral systems where expert care is lacking, among other interventions, will greatly help the response to the needs of cut women and girls while preventing new FGM/C cases.

This analysis underscores the health impacts associated with FGM/C and compelling reasons for their interventions. Overall, the recommended interventions were informed by recommended best practices based on study reports, experts, and the strength of the available evidence.

Women's health is a human rights issue and women's empowerment cannot be separated from issues related to women's health. Therefore, a comprehensive, user-friendly training guide is required. Moving forward, Evidence to End FGM/C: Research to Help Girls and Women Thrive plans to collaboratively review existing curricula and related materials for health professionals before these much-needed training materials and guidelines for health care providers can be drafted; and to conduct new research to deepen understanding on all the health impacts of $\mathrm{FGM} / \mathrm{C}$ and their interventions. 


\subsection{BACKGROUND}

\subsection{Context}

Female genital mutilation/cutting (FGM/C) is a culturally entrenched global practice that not only is considered an evident human rights violation but also has resultant health and social repercussions on girls and women. It has been implicated in serious health consequences, significant morbidity, health burden, and poor health indicators [1, 2]. A sizeable body of evidence has been developed over the past three decades on the direct health impacts of FGM/C. Systematic reviews by the Norwegian Knowledge Centre for the Health Services provide a useful summary of these impacts, organized into obstetric, gynecological, and immediate health consequences depending on the type of FGM/C [3]. There are four documented types of FGM/C: clitoridectomy (type 1), the partial or total removal of the clitoris and prepuce; excision (type II), the partial or total removal of the clitoris and the labia minora; infibulations (type III), the narrowing of the vaginal orifice through creation of a covering seal by cutting and placing together the inner and/or outer labia with or without the removal of the clitoris; and others (type IV), including non-therapeutic harmful procedures to the female genitalia such as pricking, piercing, incising, scraping, and cauterization [2]. Researchers have alluded to the fact that $\mathrm{FGM} / \mathrm{C}$ has also been associated with social, sexual, psychological, and mental consequences for women and girls.

To enable health practitioners to address the consequences associated with FGM/C, WHO, various ministries of health, organizations, and experts have presented information in the form of training and intervention materials. Currently, however, there is no single comprehensive reference material and practitioners are required to consult various materials when faced with an FGM/C challenge. This can be inefficient and wasteful in terms of time for both clients and providers, and in some cases may result in serious complications or the loss of life. Therefore, a comprehensive package of interventions, skills support, and training materials on health impacts associated with FGM/C would be most useful to health practitioners. Such materials would support the provision of appropriate, efficient, and effective gynecological, obstetric, medical, and related treatment services, including preventive strategies.

This synthesis has been spearheaded by the ACCAF team, with support from the Population Council and in consultation with recognized professional experts in the field of FGM/C, including WHO and FIGO.

\subsection{Rationale}

This review synthesis describes the health consequences of FGM/C, identifies recommended interventions, and assesses existing interventional and training materials with an aim toward informing a formal review of curricula and the development of user-friendly materials for mitigating the health consequences of FGM/C. The review is composed of three components: the health impacts associated with $\mathrm{FGM} / \mathrm{C}$, the medical and socio-community interventions recommended for the consequences, and analyses of FGM/C reference materials for inculcating knowledge, management skills, and prevention of the practice by health practitioners. The components of this review document are interrelated and are intended to synergize each other seamlessly. 


\subsection{APPROACH AND METHODS}

\subsection{Objectives}

The ultimate goals of this review are to support recommendations for the development of appropriate, user-friendly training materials and resources for use in medical training colleges for trainee health providers; and to inform the in-service and/or continuous medical education for health care providers already working in high-prevalence FGM/C areas, for appropriate corrective as well as preventive interventions in the various settings.

To achieve this goal, the following specific objectives were addressed:

i. Review existing systematic reviews, meta-analyses, and published studies to identify the strongest evidence concerning FGM/C-related health outcomes for which interventions could be recommended.

ii. Identify medical and socio-community interventions that have been recommended for the health consequences associated with $\mathrm{FGM} / \mathrm{C}$ and its prevention.

iii. Compile, review, and identify strengths and weaknesses of existing reference materials and propose improvements that would enhance pre-service training for frontline health care providers and that could be adapted for in-service training courses.

\subsection{Desk review}

The review of the literature was conducted using the terms "female genital mutilation," "female genital cutting," or "female circumcision" combined with medical subject heading (MeSH) terms "obstetrics," "gynecologic," psychologic," and "women's health" and keywords "health impacts," "health effects," "health outcomes," "health consequences," "interventions," "training manual," and "training guidelines." Databases, including PubMed/MEDLINE, were searched applying the following parameters: year of publication between 1985 and 2015; human; and in the English language. The titles and abstracts of all articles identified through the literature search were scanned for relevance. Documents were selected for full review if they specifically mentioned FGM/C and reported data on health impacts, interventions, prevention, and training materials related to FGM/C. Human observational studies were reviewed, including cross-sectional, casecontrol, prospective, and comparative studies; meta-analyses conducted on existing studies data; and cohort or population-based studies that used quantitative methodology. The respondents included women, girls, and health professionals, such as obstetricians, gynecologists, nurses, midwives, and researchers. The review included health impacts associated with $\mathrm{FGM} / \mathrm{C}$, recommended prevention and interventions to mitigate the health effects, and materials that should be included in training as a requirement for health care providers to care for women and girls affected by FGM/C and for prevention of the practice. Publications were excluded if they used qualitative study designs because of the non-randomized nature of sampling techniques and the pitfalls thereof; were not in English and could not be translated by default language translation software; or were more than 30 years old.

Quality measures for considering the systematic reviews and research reports included: sample description (details included women and girls with all types of FGM/C, nationality, and age of respondents); sampling method (description of site/setting and sampling procedure); credibility 
of researcher/author (professional midwife, nurse, obstetrician, gynecologist, surgeon, or researcher); and whether or not the systematic reviews were reviewed by content experts. Additionally, the reviewed papers offered citation sources for health outcomes, their interventions, and prevention and training guidelines for health professionals. These citations were subjected to PubMed/MEDLINE databases for retrieval and scrutinized to meet the aforementioned criteria. To supplement this process, other literature and training materials that were not available online were obtained from ACCAF, Population Council, and subject matter experts. Data were extracted and then any inconsistencies were resolved by checking full-text versions of the documents, counterchecking against the latest literature, and discussing with field experts.

\subsection{Data and analysis}

After reviewing relevant documents and identifying the $\mathrm{FGM} / \mathrm{C}$ health consequences, the reference materials were compiled and scored, and recommended interventions were outlined. The compilation involved systematically assessing the evidence within the existing reference materials and published studies. The components of FGM/C in each individual piece of evidence were assessed using a standard data abstraction form that included 17 review criteria (Box 1). The criteria were developed based on a combination of different categories as provided in three guideline documents $[4,5$, 6 ] and formed the basis for analysing what should be included in comprehensive, userfriendly training materials.

Each individual reference material was assessed based on the presence of key components of FGM/C (Box 1). Their strengths and weaknesses were further determined based on details and depth of

Box 1: Seventeen review criteria developed for assessing FGM/C reference materials

No. Criteria: Key components of FGM/C Present $=\boldsymbol{V} \quad$ Absent $=0$

1 Background and description of FGM/C

2 Complications of FGM/C

3 FGM/C and human rights

4 FGM/C management during pregnancy, labor, delivery, and postpartum period

5 Management of girls and women with gynecological complications

6 Management of girls and women with sexual complications

7 Management of girls and women with psychological/mental complications

8 Counseling

9 Medicalization

10 Professional ethics and legal implications of FGM/C

11 Community involvement in prevention of FGM/C

12 Community health education and advocacy

13 FGM/C and family planning

14 Referral procedure

15 Research

16 Training

17 Monitoring and evaluation content material elaboration.

A total of 44 reference materials were compiled, analysed, and categorised into three groups: interventional ( $73 \% ; n=32)$, training materials $(11 \% ; n=5)$, and research reports $(16 \% ; n=7)$, respectively. The analyses of the materials involved ascertaining whether or not they captured the specific FGM/C components in the 17 review criteria. The analyses of the materials based on the criteria outlined in Box 1 yielded the following key insights as presented in Tables 1 and 2. 
Table 1. Percentage score of reference material based on 17 review criteria

\begin{tabular}{l} 
Percentage category (\%) \\
\hline 75 and above \\
\hline $50-74$ \\
\hline $25-49$ \\
\hline $0-24$ \\
\hline Highest \\
\hline Lowest \\
\hline
\end{tabular}

\begin{tabular}{|c|c|}
\hline Score out of 17 & Frequency $n(\%)$ \\
\hline $13-17$ & $5(10)$ \\
\hline $9-12$ & $6(13)$ \\
\hline $4-8$ & $16(33)$ \\
\hline $0-3$ & $21(44)$ \\
\hline $15(88 \%)$ & $3(7)$ \\
\hline $1(6 \%)$ & $5(11)$ \\
\hline
\end{tabular}

Table 2. The overall scores on specific FGM/C components for the reviewed reference materials

\begin{tabular}{|r|l|c|}
\hline S/No & Components of FGM/C & Scores, $n(\%)$ \\
\hline 1 & Background and description of FGM/C & $42(96)$ \\
\hline 2 & Complications of FGM/C & $41(93)$ \\
\hline 3 & FGM/C and human rights & $29(66)$ \\
\hline 4 & $\begin{array}{l}\text { FGM/C management during pregnancy, labour, delivery, and postpartum } \\
\text { period }\end{array}$ & $26(59)$ \\
\hline 5 & Management of girls and women with gynecological complications & $24(55)$ \\
\hline 6 & Management of girls and women with sexual complications & $19(43)$ \\
\hline 7 & Management of girls and women with psychological/mental complications & $18(41)$ \\
\hline 8 & Counseling & $22(50)$ \\
\hline 9 & Medicalisation & $26(59)$ \\
\hline 10 & Professional ethics and legal implications of FGM/C & $32(73)$ \\
\hline 11 & Community involvement in prevention of FGM/C & $25(57)$ \\
\hline 12 & Community health education and advocacy & $25(57)$ \\
\hline 13 & FGM/C and family planning & $11(25)$ \\
\hline 14 & Referral procedure & $16(36)$ \\
\hline 15 & Research & $23(52)$ \\
\hline 16 & Training & $14(32)$ \\
\hline 17 & Monitoring and evaluation & $11(25)$ \\
\hline
\end{tabular}

Of the 44 reference materials analysed using the 17 review criteria for FGM/C components, the highest score was $15(6.8 \%, n=3)$ while the lowest was $1(11.4 \%, n=5)$ (Table 1$)$. Only 10.4\% $(n=5)$ scored $75 \%$ and above, while $12.5 \%(n=6)$ scored 50 to $74 \%$ on the 17 -point criteria. More than $75 \%(n=20)$ of the analysed reference materials contained less than $50 \%$ of the key FGM/C components. The highest (88.2\%) score was 15 , achieved by $6.8 \%(n=3)$, while the lowest $(5.9 \%)$ score was 1 , attained by $11.4 \%(n=5)$ of the reference materials, respectively. Only $25 \%(n=11)$ of the reference materials met $50 \%$ and above of the criteria. On the other hand, $40.9 \%(n=18)$ of the materials scored below $25 \%$ of the criteria.

\subsection{REVIEW FINDINGS}

\subsection{Synthesis of evidence: Health impacts}

This section outlines the health impacts attributable to FGM/C as collected from the systematic reviews, meta-analyses, and published studies conducted in the past three decades. The review identified 5 categories of health impacts attributable to FGM/C: immediate, genito-urinary, obstetric, sexual, and psycho-social complications. The health impacts described in the sections below, based on available scientific evidence on FGM/C accumulated over the last three 
decades, warrant interventions by health care providers in health facilities as well as in community settings.

\subsubsection{Immediate (acute) complications}

The cutting of women's and girls' clitoris and labia is usually done with crude unsterile instruments and without anesthesia, by traditional practitioners who have little knowledge of female anatomy [7]. The cutting results in immediate harm. Bleeding (haemorrhage) occurs due to laceration or severing of branches of the pudendal or clitoral arteries, which have high blood pressure, causing a strong flow of blood during and shortly after the cutting process. Other immediate complications include shock, genital tissue swelling, fever, infections, problems with urination (acute urinary retention, hesitancy), and delayed wound healing, as corroborated by observational studies involving large samples of women and girls of various ages who had undergone various types of FGM/C [3] and by study reports [8, 9]. Evidence also shows that girls suffer more than one immediate complication, and in some cases deaths have been attributed directly to FGM/C [10-14]. Death can result from severe bleeding, pain and trauma, severe and overwhelming infection, or a combination of these complications. The immediate harms vary with the type of FGM/C, with the greatest risk seen among type III, relative to types I and II [15] (Table 3).

The evidence on the magnitude of immediate complications associated with FGM/C varied across the reviewed studies. This variation may have been due to under-reporting of the complications or to the timing of post-procedure observations. Some studies have reported very high rates of girls who have undergone $\mathrm{FGM} / \mathrm{C}$ but experienced no bleeding $[15,16]$. Such disparities may be the result of methodological differences in data collection, with clinical assessment likely to be more objective and accurate, while self-reporting may result in gross under-reporting. This reasoning is supported by the fact that many women underwent FGM/C as infants or children and they may not remember any immediate adverse effects. Furthermore, women may not link complications arising during childbirth or later in life to the genital cutting they underwent as children. Additionally, FGM/C-related complications may be considered as normal and natural to women, especially among populations where FGM/C is nearly universal, due to social norms [17]. 
Table 3. Immediate (acute) outcomes attributed to FGM/C

\begin{tabular}{|c|c|c|c|c|c|}
\hline Outcome & Reasons & $\begin{array}{l}\text { Number of } \\
\text { studies/type }\end{array}$ & $\begin{array}{l}\text { Sample } \\
\text { size }(n)\end{array}$ & $(\mathbf{S}) /(\mathrm{NS})^{1}$ & References \\
\hline Bleeding & $\begin{array}{l}\text { Laceration to pudendal and/or clitoral } \\
\text { arteries, which have high flow and } \\
\text { pressure }\end{array}$ & \multirow[t]{9}{*}{$\begin{array}{l}56 / \\
\text { Observational } \\
\text { Representative }\end{array}$} & \multirow[t]{9}{*}{133,515} & \multirow[t]{9}{*}{ S } & \multirow{9}{*}{$\begin{array}{l}\text { El Dareer } \\
\text { 1983; Trew } \\
\text { 2013; Migiro } \\
\text { 2014; Asuen } \\
\text { 1977; Badejo } \\
\text { 1983; Osifo \& } \\
\text { Evbuomwan }\end{array}$} \\
\hline Pain & $\begin{array}{l}\text { Injuries to cut tissues and nerves, swelling } \\
\text { and pressure, no anesthesia }\end{array}$ & & & & \\
\hline Shock & $\begin{array}{l}\text { Blood loss (haemorrhagic shock), severe } \\
\text { pain and trauma (neurogenic shock), which } \\
\text { can be fatal }\end{array}$ & & & & \\
\hline $\begin{array}{l}\text { Genital } \\
\text { tissue } \\
\text { swelling }\end{array}$ & $\begin{array}{l}\text { Trauma and injured tissues of urethra, } \\
\text { vagina, perineum, and rectum }\end{array}$ & & & & \\
\hline Fever & Inflammation, trauma, infection & & & & \\
\hline Infections & $\begin{array}{l}\text { Unsterile procedure, skin destruction (e.g., } \\
\text { tetanus, hepatitis, HIV) }\end{array}$ & & & & \\
\hline $\begin{array}{l}\text { Urination } \\
\text { problems }\end{array}$ & $\begin{array}{l}\text { Swelling, inflammation around the wound, } \\
\text { fear of pain of passing urine on the raw } \\
\text { wound, or injury to the urethra }\end{array}$ & & & & \\
\hline $\begin{array}{l}\text { Delayed } \\
\text { wound } \\
\text { healing }\end{array}$ & $\begin{array}{l}\text { Failure of wound to heal due to infection, } \\
\text { irritation from urine or rubbing when } \\
\text { walking, or an underlying condition, such } \\
\text { as anemia or malnutrition }\end{array}$ & & & & \\
\hline Death & $\begin{array}{l}\text { Severe bleeding, pain, and trauma, or } \\
\text { severe and overwhelming infection, or a } \\
\text { combination of the above }\end{array}$ & & & & \\
\hline
\end{tabular}

\subsubsection{Late (chronic) genito-urinary problems}

Female genital cutting is associated with chronic problems affecting the genital and/or urinary systems of women and girls. This has been corroborated by several comparative studies involving large numbers of women and girls $[3,18,19]$. The specific genito-urinary problems commonly reported include: genital tissue damage, vaginal discharge, itching, urological complications, and infections [3]. In light of this evidence, interventions for these complications should be developed. Other genito-urinary outcomes such as scarring, keloids, abscesses, fistulae, damaged tissue (perineum, anal sphincter), disfigurement, vaginal obstruction, and cysts are rarely encountered in the research reports, possibly because of lack of rigorous research and documentation [3]. This may be due to methodological differences in data collection and the fact that most studies do not disaggregate chronic genital urinary problems data against the type of cutting, which may affect the interpretation of the data [3] (Table 4). Additionally, some outcomes, such as HIV, STDs, and infertility, are rarely encountered in the literature and not reported.

\footnotetext{
${ }^{1} \mathrm{~S}=$ significant; NS=not significant
} 
Table 4. Late (chronic) genito-urinary outcomes attributed to FGM/C

\begin{tabular}{|c|c|c|c|c|c|c|}
\hline Outcome & $\begin{array}{l}\text { Rationale for the } \\
\text { outcome }\end{array}$ & Study type & Studies & $\begin{array}{l}\text { Sample } \\
\text { size }(n)\end{array}$ & $\begin{array}{l}\text { (S) / } \\
(\text { NS) }\end{array}$ & References \\
\hline $\begin{array}{l}\text { Vaginal } \\
\text { discharge }\end{array}$ & Infections & $\begin{array}{l}\text { Cross- } \\
\text { sectional }\end{array}$ & 4 & 3,657 & S & $\begin{array}{l}\text { Nwanjei \& Otiono 2003; } \\
\text { Okonofu et al. } 2002 \text {; Elnashar } \\
\text { \& Abdelhady } 2007\end{array}$ \\
\hline $\begin{array}{l}\text { Vaginal } \\
\text { itching }\end{array}$ & $\begin{array}{l}\text { Infections, trauma, } \\
\text { reaction due to } \\
\text { discharge }\end{array}$ & $\begin{array}{l}\text { Cross- } \\
\text { sectional }\end{array}$ & 4 & 3,657 & $\mathrm{~S}$ & $\begin{array}{l}\text { Morrone et al. 2002; Okonofu } \\
\text { et al. 2002; Elnashar \& } \\
\text { Abdelhady } 2007\end{array}$ \\
\hline $\begin{array}{l}\text { Painful } \\
\text { urination }\end{array}$ & $\begin{array}{l}\text { Damage to the } \\
\text { urethral opening or } \\
\text { scarring of the } \\
\text { meatus }\end{array}$ & Comparative & 6 & 3,611 & $\mathrm{~S}$ & $\begin{array}{l}\text { Morison et al. 2001; Okonofu } \\
\text { et al. 2002; Elnashar \& } \\
\text { Abdelhady 2007; De Silva } \\
1989\end{array}$ \\
\hline $\begin{array}{l}\text { Menstrual } \\
\text { problems }^{3}\end{array}$ & $\begin{array}{l}\text { Due to partial or total } \\
\text { occlusion of the } \\
\text { vaginal opening }\end{array}$ & $\begin{array}{l}\text { Cross- } \\
\text { sectional }\end{array}$ & 5 & 6,564 & $\mathrm{~S}$ & $\begin{array}{l}\text { INSEED 2005; El Defrawi et al. } \\
\text { 2001; Morrone et al. 2002; } \\
\text { Nwajei \& Al Otieono } 2003\end{array}$ \\
\hline $\begin{array}{l}\text { Chronic } \\
\text { genito-urinary } \\
\text { infections }\end{array}$ & $\begin{array}{l}\text { Ascending urinary } \\
\text { tract infections }\end{array}$ & Comparative & 10 & 28,940 & $\mathrm{~S}$ & $\begin{array}{l}\text { INSEED 2005; El Defrawi et al. } \\
\text { 2001; Fillo \& Leone } 2007\end{array}$ \\
\hline $\begin{array}{l}\text { Reproductive } \\
\text { tract } \\
\text { infections }\end{array}$ & $\begin{array}{l}\text { Occlusion of the } \\
\text { vagina and urethra } \\
\text { causing stasis and } \\
\text { climbing of the } \\
\text { infections }\end{array}$ & $\begin{array}{l}\text { Cross- } \\
\text { sectional } \\
\text { Prospective }\end{array}$ & 2 & 2,412 & $\mathrm{~S}$ & $\begin{array}{l}\text { Jones et al. 1999; Brewer et al. } \\
2007\end{array}$ \\
\hline $\begin{array}{l}\text { Genital } \\
\text { infections }\end{array}$ & $\begin{array}{l}\text { Trauma, entry of } \\
\text { infectious organisms, } \\
\text { inflammation due to } \\
\text { discharge }\end{array}$ & $\begin{array}{l}\text { Cross- } \\
\text { sectional } \\
\text { Prospective }\end{array}$ & 2 & 2,412 & $\mathrm{~S}$ & $\begin{array}{l}\text { Jones et al. 1999; Brewer et al. } \\
2007\end{array}$ \\
\hline $\begin{array}{l}\text { Urinary tract } \\
\text { Infections }\end{array}$ & $\begin{array}{l}\text { Occlusion of the } \\
\text { urethra }\end{array}$ & Meta-analyses & 5 & 9,414 & $\mathrm{~S}$ & $\begin{array}{l}\text { INSEED 2005; El Defrawi et al. } \\
\text { 2001; Browning et al. 2010; } \\
\text { Fillo \& Leone } 2007\end{array}$ \\
\hline $\begin{array}{l}\text { Bacterial } \\
\text { vaginosis }\end{array}$ & $\begin{array}{l}\text { Trauma, entry of } \\
\text { infectious organisms, } \\
\text { reaction due to } \\
\text { discharge }\end{array}$ & Meta-analyses & 5 & 9,414 & $\mathrm{~S}$ & Nwajei \& Otiono 2003 \\
\hline $\begin{array}{l}\text { Genital tissue } \\
\text { damage }\end{array}$ & $\begin{array}{l}\text { Trauma due to } \\
\text { FGM/C, inflammation } \\
\text { due to discharge, } \\
\text { infections }\end{array}$ & $\begin{array}{l}\text { Cross- } \\
\text { sectional }\end{array}$ & 4 & 3,657 & NS & $\begin{array}{l}\text { Morison et al. 2001; Nwajei \& } \\
\text { Otiono 2003; Okonofu et al. } \\
\text { 2002; Elnashar \& Abdelhady } \\
2007\end{array}$ \\
\hline HIV & $\begin{array}{l}\text { Small vaginal } \\
\text { opening, cuts and } \\
\text { tears, sharing of } \\
\text { cutting instruments }\end{array}$ & $\begin{array}{l}\text { Case-control } \\
\text { Cross- } \\
\text { sectional }\end{array}$ & $\begin{array}{l}1 \\
10 *\end{array}$ & 12,912 & $\begin{array}{l}\text { NS } \\
\text { NS }\end{array}$ & $\begin{array}{l}\text { Klouman et al. 2005; } \\
\text { Maslovskaya et al. 2009; } \\
\text { Yount \& Abraham 2007; Balk } \\
2000\end{array}$ \\
\hline STDs & $\begin{array}{l}\text { Trauma, entry of } \\
\text { infectious organisms, } \\
\text { inflammation due to } \\
\text { discharge, poor } \\
\text { hygiene due to pain }\end{array}$ & $\begin{array}{l}\text { Case-control } \\
\text { Cross- } \\
\text { sectional }\end{array}$ & $\begin{array}{l}1 \\
10 *\end{array}$ & 12,912 & $\begin{array}{l}\text { NS } \\
\text { NS }\end{array}$ & $\begin{array}{l}\text { Nwajei \& Otiono 2003; } \\
\text { Klouman et al. 2007; } \\
\text { Maslovskaya et al. 2009; } \\
\text { Yount \& Abraham 2007; Balk } \\
2000\end{array}$ \\
\hline Infertility & $\begin{array}{l}\text { Pelvic infections, } \\
\text { damage to } \\
\text { reproductive organs, } \\
\text { painful intercourse }\end{array}$ & $\begin{array}{l}\text { Case-control } \\
\text { Cross- } \\
\text { sectional }\end{array}$ & $\begin{array}{l}2 \\
10 *\end{array}$ & 36,473 & NS & $\begin{array}{l}\text { El Defrawi et al. 2001; } \\
\text { Browning et al. 2010; Nwajei \& } \\
\text { Al Otiono 2003; Yount \& } \\
\text { Abraham 2007; Inhorn \& Buss } \\
\text { 1993; Jackson et al. 2005; } \\
\text { Larsen \& Okonofua 2002; Berg } \\
\text { \& Underland } 2013\end{array}$ \\
\hline
\end{tabular}

* The higher number represents case-control studies while the lower number represents cross-sectional studies.

2 S=significant; NS=not significant.

${ }^{3}$ Dysmenorrhea, difficulty in menstruation, irregular menses, and difficulty in passing menstrual blood. 
In Table 4, the complications from the late (chronic) genito-urinary outcomes attributed to FGM/C were gleaned from systematic reviews and study reports. Corrective and preventive interventions for both common and rare outcomes are recommended at health facilities and in community settings.

\subsubsection{Obstetric complications}

The obstetric complications, notably prolonged labour, tears and lacerations, caesarean sections, episiotomies, instrumental deliveries, postpartum haemorrhages (PPHs), and difficult labour associated with FGM/C were documented from numerous comparative studies involving large samples of women and girls [3, 35, 36] (Table 5).

Table 5. Obstetric outcomes attributed to FGM/C

\begin{tabular}{|c|c|c|c|c|c|}
\hline Outcome & Type of study & $\begin{array}{l}\text { Number of } \\
\text { studies }\end{array}$ & Sample size (n) & $(\mathbf{S}) /(\mathbf{N S})^{4}$ & References \\
\hline $\begin{array}{l}\text { Prolonged } \\
\text { labour }\end{array}$ & $\begin{array}{l}\text { Comparative } \\
\text { Prospective }\end{array}$ & $\begin{array}{l}5 \\
1\end{array}$ & $\begin{array}{l}715,079 \\
(6,324)\end{array}$ & S & $\begin{array}{l}\text { Berg et al. 2014; Berg \& } \\
\text { Underland 2013; Johnson } \\
\text { et al. 2005; Chibber et al. } \\
\text { 2011; Meirik et al. } 2006\end{array}$ \\
\hline $\begin{array}{l}\text { Tears and } \\
\text { lacerations }\end{array}$ & $\begin{array}{l}\text { Comparative } \\
\text { Prospective }\end{array}$ & 15 & $\begin{array}{l}738,672 \\
(17,961)\end{array}$ & $S$ & $\begin{array}{l}\text { Berg et al. 2014; Berg \& } \\
\text { Underland 2013; Johnson } \\
\text { et al. 2005; Chibber et al. } \\
\text { 2011; Meirik et al. 2006; } \\
\text { Wuest et al. } 2009\end{array}$ \\
\hline $\begin{array}{l}\text { Caesarean } \\
\text { section }\end{array}$ & Prospective & 15 & $\begin{array}{l}2.74 \mathrm{M} \\
(41,306)\end{array}$ & S & $\begin{array}{l}\text { Berg et al. 2014; Johnson } \\
\text { et al. 2005; Chibber et al. } \\
\text { 2011; Meirik et al. 2006; } \\
\text { Wuest et al. } 2009\end{array}$ \\
\hline Episiotomy & $\begin{array}{l}\text { Retrospective } \\
\text { Prospective }\end{array}$ & 11 & $\begin{array}{l}35,467 \\
(23,869)\end{array}$ & S & $\begin{array}{l}\text { Berg et al. 2014; Fillo \& } \\
\text { Leone 2007; Vangen et al. } \\
\text { 2002; Johnson et al. 2005; } \\
\text { Chibber et al. 2011; Berg \& } \\
\text { Denison } 2012\end{array}$ \\
\hline $\begin{array}{l}\text { Instrumental } \\
\text { delivery }\end{array}$ & $\begin{array}{l}\text { Registry study } \\
\text { Prospective } \\
\text { Cross-section }\end{array}$ & 9 & $\begin{array}{l}2.34 \mathrm{M} \\
(12,557)\end{array}$ & S & $\begin{array}{l}\text { Berg et al. 2014; Johnson } \\
\text { et al. 2005; Chibber et al. } \\
2011\end{array}$ \\
\hline $\begin{array}{l}\text { Postpartum } \\
\text { haemorrhage } \\
\text { (PPH) }\end{array}$ & Prospective & 10 & $\begin{array}{l}746,667 \\
(27,626)\end{array}$ & $S$ & $\begin{array}{l}\text { Berg et al. 2014; Johnson } \\
\text { et al. 2005; Chibber et al. } \\
2011\end{array}$ \\
\hline $\begin{array}{l}\text { Difficult } \\
\text { labour }\end{array}$ & $\begin{array}{l}\text { Prospective } \\
\text { Cross section } \\
\text { Comparative }\end{array}$ & 7 & $\begin{array}{l}11,659 \\
(3,252)\end{array}$ & S & $\begin{array}{l}\text { Berg et al. 2014; Berg et al. } \\
\text { 2014; Johnson et al. 2005; } \\
\text { Chibber et al. 2011; Wuest } \\
\text { et al. } 2009\end{array}$ \\
\hline
\end{tabular}

In Table 5, the obstetric outcomes attributed to FGM/C are shown. These complications are associated with substantial suffering by women and girls. In the reference materials, it is recommended that corrective and preventive interventions be developed and/or strengthened at the health facility and community levels to deal with these consequences.

${ }^{4} \mathrm{~S}=$ significant; NS=not significant. 


\subsubsection{Sexual functioning complications}

This synthesis revealed that FGM/C is associated with sexual complications. Women who had undergone cutting were more likely to report painful intercourse, no sexual desire, less sexual satisfaction, and less experience of orgasm compared to their uncut counterparts. Other sexual outcomes reported include women not initiating sex and lack of knowledge of the most sexually sensitive part of their bodies [42] (Table 6).

Table 6. Sexual functioning outcomes attributed to FGM/C

\begin{tabular}{|c|c|c|c|c|}
\hline Outcome & $\begin{array}{l}\text { Number of } \\
\text { studies }\end{array}$ & $\begin{array}{l}\text { Sample } \\
\text { size }(n)\end{array}$ & $\begin{array}{l}\text { (S) } \\
/(\text { NS) })^{5}\end{array}$ & Reference \\
\hline Painful intercourse & 6 & \multirow{5}{*}{$3657 *$} & S & $\begin{array}{l}\text { Berg et al. 2014; El Defrawi et al. 2001; Morrone } \\
\text { et al. 2002; Nwajei \& Otiono 2003; Elnashar \& } \\
\text { Abdelhady 2007; De Silva 1989; Adinma } 1997\end{array}$ \\
\hline Satisfaction & 5 & & S & $\begin{array}{l}\text { Morrone et al. 2002; Berg \& Denison 2012; } \\
\text { Adinma 1997; Alsibiani \& Rouzi } 2010\end{array}$ \\
\hline Sexual desire & 2 & & S & $\begin{array}{l}\text { Morrone et al. 2002; Adinma 1997; Thabet \& } \\
\text { Thabet 2003; Shandall } 1967\end{array}$ \\
\hline Experienced orgasm & 5 & & S & $\begin{array}{l}\text { Adinma 1997; Thabet \& Thabet 2003; Shandall } \\
\text { 1967; Megafu 1983; Rushwan } 2000\end{array}$ \\
\hline Initiated sex & 2 & & NS & $\begin{array}{l}\text { Morrone et al. 2002; Elnashar \& Abdelhady } \\
\text { 2007; Adinma } 1997\end{array}$ \\
\hline
\end{tabular}

* Cross-sectional studies

Table 6 outlines the sexual functioning outcomes attributed to FGM/C. The corrective and preventive interventions for sexual complications should include strategies for identification, management, monitoring, and prevention.

\subsubsection{Psycho-social complications}

FGM/C or its delayed complications may trigger the onset of one or a combination of the following complications: acute anxieties, depression, neuroses, psychoses, and post-traumatic stress disorder. The physical complications arising from FGM/C may also interfere with women's and girls' social lives because of ill health. For example, incontinence may interfere with their full participation in social activities and lead to isolation. Difficult penetration and infertility affect sexual life and may precipitate divorce [48]. The findings under this outcome were inconclusive because of the small number of studies that were reviewed, as well as the low quality of the methodological approach of the studies.

\footnotetext{
${ }^{5}$ S=significant; NS=not significant
} 


\subsection{Synthesis of evidence: Curative and preventive interventions recommended for health impacts of FGM/C}

The review revealed various complications associated with $\mathrm{FGM} / \mathrm{C}$. This section outlines the interventions as recommended in these materials for alleviating and preventing $\mathrm{FGM} / \mathrm{C}$ associated complications, both in health facilities and in socio-community settings. The section also forms the basis for reviewing existing interventions and/or training materials, curriculum, and capacity building for health professionals, with a view toward strengthening training materials and resources to provide better care for women and girls exposed to FGM/C and to prevent the practice.

\subsubsection{Training of health care professionals}

Public health services play a critical role in the prevention and mitigation of FGM/C and its harmful effects on women's health. Thus the training of health care providers will be a key response. The materials recommend that training of health care professionals include comprehensive and technical knowledge about FGM/C to aid in promoting abandonment of FGM/C practices and to enable clinical management of those impacted by FGM/C. For example:

- Frontline health care providers should be aware of the impacts, including immediate, physical, sexual, psychological, and social, associated with FGM/C and should consider the practice when assessing, managing, counseling, and/or referring women and girls for reproductive, pregnancy, and delivery health services.

- As a result of the immediate (acute) nature of the complications caused by FGM/C, women and girls present to health facilities in very desperate conditions, requiring quick and effective interventions. It is recommended that health care professionals (doctors, nurses, and midwives) should be well-trained in the diagnosis and management of FGM/C-associated complications in patients who are admitted to or visit outpatient clinics immediately following genital cutting.

- To deal with late (chronic) complications such as dermoid cysts and keloids, it is recommended that health professionals be trained to recognize, advise, counsel, and treat patients with these complications, as well as to perform curative procedures such as fistula repair and deinfibulation [49-54].

- It is recommended that hospitals in FGM/Cendemic areas have their health care providers trained on caring for FGM/C-exposed women. Since infibulated women run the highest risk during labour, doctors, nurses, and midwives should be trained to develop expertise in the assessment and management of women with infibulations, including competencies to carry out de-infibulation and management after deinfibulation (Box 2) $[55,56]$.

Box 2: Example: Skill sets for deinfibulation

Recommendation: Women must undergo de-infibulation before conception, especially if difficult surgery is anticipated.

- Doctors, nurses, and midwives are trained to develop expertise in the assessment and management of women with infibulations and following de-infibulation.

- Clients are counseled that deinfibulation can restore an opening to the vaginal canal to allow for normal urination, menstrual flow, and sexual intercourse.

- Psychosexual counseling should be provided before and after deinfibulation.

- De-infibulation may be carried out in any suitable outpatient room equipped for minor procedures or in an operating theatre. 


\subsubsection{Provision of counseling and psycho-social support}

There is increasing evidence that "FGM and its associated health risks are psychological stressors that can lead to a variety of negative psychological and psychiatric outcomes" [57]. Recommendations for health care providers include the following:

- Provide counseling and advice to clients based on anticipated complications associated with $\mathrm{FGM} / \mathrm{C}$, including encouraging women to deliver in a hospital with qualified assistance.

- Recognize the underlying psychological complications of $\mathrm{FGM} / \mathrm{C}$ and refer women and girls for appropriate psychological/counseling care.

- Utilize cognitive behavioural therapy, which has been found to be effective in preventing and treating post-traumatic stress disorder.

- Establish institutional, peer, and community-based counseling groups.

- Recognize the sexual problems that women face as a result of FGM/C and routinely provide counseling for women with such complaints.

- Initiate referral mechanisms, including linking clients with qualified sexologists.

- Provide counseling and psycho-social support interventions for clients who access health facilities, as well as for those in community settings. The role of sexologists and sexual therapy should be pursued.

\subsubsection{Addressing social conventions and norms and creating awareness}

Health care providers play a key role in raising people's awareness, bringing attention to the health impacts of $\mathrm{FGM} / \mathrm{C}$ and encouraging behaviour change in the social conventions and norms that underpin the practices of FGM/C. The review illuminates the need to:

- Enhance capacity of health care providers to raise awareness of the health impacts associated with FGM/C and encourage them in their roles as advocates, role models, counselors, and caretakers to contribute to the mitigation and abandonment of the practice [58-60].

- Anchor FGM/C preventive messages to existing reproductive health programs in health facilities, as well as in community settings, which will go a long way towards prevention and management of these complications.

- Familiarize all maternity healthcare providers with the nature and higher rates of complications related to FGM/C.

- Encourage women and girls to seek medical care if they have complications, because such complications may become intensified or even cause death, and also encourage them to avoid traditional remedies because the use of herbs can lead to severe bleeding or introduction of infections [48].

- Support health care providers in establishing community approaches to dealing with consequences of FGM/C (e.g., community psycho-social support, debriefings, and establishment of networks). 
- Sensitize communities to the fact that some of the reproductive and medical complications women and girls present with at health service points are associated with $\mathrm{FGM} / \mathrm{C}$ and that they can be traced to childhood trauma such as FGM/C. Raising awareness in this manner would enhance identification of the complications and lead to better-health seeking behaviour and promotion of preventive strategies.

- Involve local administration, law enforcement, prosecutors, and the judiciary in raising awareness in communities about anti-FGM/C laws and the consequences of breaking these laws, and increasing knowledge about prosecutions and penalties.

- Lay the foundation for norm change by educating communities and professionals that $\mathrm{FGM} / \mathrm{C}$ is a violation of human rights and raising community awareness about the global instruments against FGM/C, notably the United Nation General Assembly and Human Rights Council of 2012 and 2014 resolutions [42, 58, 61-63].

- Undertake concerted educational interventions involving all stakeholders on the facts about FGM/C, thereby counteracting myths that are used to perpetuate the practice, such as "FGM/C is supported by religion," and "the practice makes woman more fertile," among others.

- Dissociate FGM/C from religion by involving religious leaders and the community through capacity building [59].

- Partner with communities to develop abandonment strategies for FGM/C, including participation in documentation, anonymous reporting, monitoring, and tracking of the $\mathrm{FGM} / \mathrm{C}$ practice.

- Encourage traditional excisors to abandon the practice and empower them to obtain income from other means.

- Empower women and girls through economic opportunities, education for the girl child, and dissociation of FGM/C from dowries.

- Establish anti-FGM/C campaigns among community structures and formal institutions like schools and churches to accelerate abandonment.

- Involve both men and women in the fight against FGM/C, helping them to associate the practice with its health consequences and thereby accelerating its abandonment.

\subsubsection{Strengthening health systems}

Health systems should be strengthened to respond to the health impacts of FGM/C on women and girls in the following ways:

- Develop intervention protocols, given the nature and seriousness of FGM/C complications. Cascade protocols to all health care facilities, especially in FGM/Cprevalent areas. Establish referral and supervisory mechanisms to address those complications where expert care is lacking.

- Integrate FGM/C strategies into existing health care delivery, including reproductive health, family planning, and youth-friendly services, among others, to leverage and maximize cost effectiveness.

- Support capacity building for facilities and health care providers, including supervision. 
- Review curricula in order to benefit health care trainees in training colleges.

- Provide facilities with equipment and supplies for addressing FGM/C complications.

- Equip health facilities to be able to deliver health and sexual education to women with FGM/C-related complaints.

- Lobby for the strengthening of the health care system to respond to FGM/C challenges, including the establishment of efficient referral systems and the financing and buying of supplies.

- Establish supervisory and referral mechanisms to track and report cases, including information on how cases were resolved.

- Involve professional associations and regulatory bodies to create awareness among professional members of complications of FGM/C, including medicalised cutting; illegality of FGM/C; and penalties for medicalisation, including de-registration of violators [64, 65].

\subsubsection{Documentation and research}

Developing, and facilitating access to, information resources and databanks will be vital to designing appropriate responses to specific contexts to address the health impacts of $\mathrm{FGM} / \mathrm{C}$. From the evidence gathered, the following interventions have been recommended.

- Research and analyses of the impact on babies and infants who have undergone FGM/C are highly recommended.

- Research into psychological consequences associated with FGM/C needs to be prioritized. Too little research has been performed to date to establish the true association between FGM/C and psychological disorders.

- More research is needed that uses rigorous methodological design to further document the sexual complications of FGM/C.

- A large study with a more rigorous methodology is needed to elicit the psycho-social consequences of FGM/C and hence inform programming. Multidisciplinary and multifactorial causes should also be considered since FGM/C is often one of the factors resulting in mental consequences, alongside others such as migration and other past violent events. Therefore, consideration of the mental consequences of FGM/C should be given priority for research, as should interventions through counseling and psychotherapy.

- Additionally, further research should be conducted on the rare outcomes associated with FGM/C. HIV, STDs, and infertility are rarely encountered in the literature and are not reported. Therefore, further research is recommended to establish whether the findings may be replicated. Because these medical complications, which are of public health importance, are infrequently reported and therefore lack statistical significance, it is recommended that high-level methodological research on these complications be conducted.

- Furthermore, more rigorous methodological (case controlled, randomized, and longitudinal) and large-scale studies should be conducted in the area of sexual function. 


\subsection{Improvements to enhance pre-service training for frontline health care providers}

The analysis revealed various types of gaps in the reference materials. The materials varied in the depth and coverage of the details of the FGM/C components (Tables 1 and 2). Whereas the materials were strong on background information, they were typically weak on coverage of interventions. Of the 44 analysed materials, most $(96 \% ; n=42)$ had detailed background and introduction information. The materials scored marginally on obstetric $(59 \% ; n=26)$, gynecologic (55\%; $n=24)$, counseling ( $50 \% ; n=22)$, medicalisation ( $59 \% ; n=26)$, and community involvement $(57 \% ; n=25)$ themes. The analysis further revealed glaring deficits in the depth of content on the skills enhancement and training materials on FGM/C. The materials rated poorly on sexual (43\%; $n=19)$, psychological/mental $(41 \% ; n=18)$, family planning $(25 \% ; n=11)$, referral procedure $(36 \%$; $n=16)$, and monitoring and evaluation ( $25 \% ; n=11)$ components.

The analysis demonstrated that the background information, including the epidemiology of FGM/C, was well covered in almost all the reference materials. There are numerous studies on the "what," "why," and "who" questions about FGM/C in an endeavor to understand the practice [4]. The components of $\mathrm{FGM} / \mathrm{C}$ that are critical for interventions and protocols in caring for women and girls with health complications, such as obstetric, gynecologic, counseling, medicalisation, and research components, were marginally addressed. Furthermore, other components such as sexual, psychological, mental health, family planning, referral procedure, monitoring, and evaluation components, were poorly covered. This shortcoming could be attributed to lack of scientific evidence as a result of poor or no research in these critical areas.

The components may be suffering neglect due to an underestimation of their magnitude, as a result of inadequate evidence and funding. Whereas maternal and child issues have received considerable attention and funding, the psychological and sexual impacts of FGM/C have been neglected $[3,66]$. These shortcomings in the reference materials may have serious implications for the management of women and girls living with FGM/C and for the fight against the practice in health facility and community settings. There is greater need, therefore, to develop a comprehensive, user-friendly training guide and provide skills enhancement support and training materials for FGM/C frontline health care professionals working in the curative sector, as well as for those in the preventive sectors, to accelerate abandonment of the practice.

The analyses further revealed glaring gaps in both curative and preventive interventions protocols. This is possibly due to the lack of evidence and assessment of interventions for most of the identified health outcomes [3]. Several interventions are recommended in order to enhance training, programming, and messaging for medical care providers such as: establishing referral systems where expert care is lacking, strengthening health care systems to respond to FGM/C challenges, and building the capacity of frontline health care professionals to enable them to offer curative and preventive services in FGM/C-prevalent areas (Table 7). The findings also highlight the importance of anchoring preventive interventions for FGM/C to existing community health care systems and socio-community structures, especially in high-prevalence areas, in order to address challenges faced by cut girls and women while preventing new FGM/C cases. The review findings therefore recommend the development of comprehensive, userfriendly training guides and resource materials that are suitable for professionals who work in the hospital setting (curative) as well as community (preventive) sectors of health. Furthermore, more studies need to be conducted to fill the gaps identified in the health impacts of FGM/C to address the methodological pitfalls affecting some of the thematic areas, such as the sexual and psychological domains [3]. 


\begin{tabular}{|c|c|c|}
\hline Health Impacts & Recommended Curative and Preventive Interventions & $\begin{array}{l}\text { Gaps found in training } \\
\text { materials, interventions, } \\
\text { messaging, and research } \\
\text { on health impacts }\end{array}$ \\
\hline $\begin{array}{l}\text { Immediate } \\
\text { (acute) } \\
\text { complications }\end{array}$ & $\begin{array}{l}\text { - Health assessment for early accurate diagnosis of complications } \\
\text { - Fluid replacement therapy including blood transfusion } \\
\text { - Anti-pain therapy } \\
\text { - Immunization against tetanus } \\
\text { - Antibiotic therapy for infections } \\
\text { - Surgical management including infection control and prevention } \\
\text { - Health education (awareness) linking FGM/C to complications } \\
\text { - Advocacy towards seeking medical assistance and avoidance of traditional herbs } \\
\text { - Documentation, monitoring, and evaluation, including integration of FGM/C cases into health statistics reporting systems } \\
\text { - Establishment of efficient referral mechanisms } \\
\text { - Engagement of all stakeholders to raise awareness among communities about anti-FGM/C laws, implications of breaking these } \\
\text { laws, and human right violations; clarify myths about the practice; and dissociate the practice from religion }\end{array}$ & $\begin{array}{l}\text { - Interventions and } \\
\text { protocols for managing } \\
\text { women with health } \\
\text { complications such as } \\
\text { obstetric and gynecologic } \\
\text { complications, } \\
\text { counseling needs, } \\
\text { medicalisation, and } \\
\text { research, were } \\
\text { marginally addressed in }\end{array}$ \\
\hline $\begin{array}{l}\text { Late (chronic) } \\
\text { genito-urinary } \\
\text { problems }\end{array}$ & $\begin{array}{l}\text { - Health assessment for early accurate diagnosis } \\
\text { - De-infibulation } \\
\text { - Surgical/wound care management including plastic surgery } \\
\text { - Establishment of efficient and referral mechanisms } \\
\text { - Antibiotic therapy for infections } \\
\text { - Infection control and prevention } \\
\text { - Health education } \\
\text { - Fistula identification, management, and care } \\
\text { - Documentation, monitoring, and evaluation }\end{array}$ & $\begin{array}{l}\text { - Sexual, psychological, } \\
\text { mental health, family } \\
\text { planning, referral } \\
\text { procedure, monitoring, } \\
\text { and evaluation were } \\
\text { poorly covered. } \\
\text { - Documentation, } \\
\text { information, and access } \\
\text { to research were absent. }\end{array}$ \\
\hline $\begin{array}{l}\text { Obstetric } \\
\text { complications }\end{array}$ & $\begin{array}{l}\text { - Health assessment for accurate diagnosis including types of FGM/C and re-infibulation cases } \\
\text { - Psychological and counseling support } \\
\text { - De-infibulation } \\
\text { - Surgical/wound care management } \\
\text { - Establishment of efficient and referral mechanisms for complicated dermoid cysts, keloids, and scarring at the time of } \\
\text { pregnancy } \\
\text { - Antibiotic therapy for urinary infections } \\
\text { - Infection control and prevention } \\
\text { - Health education, including on hospital delivery, association between FGM/C and complications, avoiding use of herbs } \\
\text { - Blood balance maintenance through bleeding control, fluid replacement, blood transfusion, hematinics } \\
\text { - Documentation, monitoring, and evaluation }\end{array}$ & $\begin{array}{l}\text { - Monitoring and } \\
\text { evaluation of health- } \\
\text { related outcomes were } \\
\text { rarely documented. } \\
\text { - Rigorous methodological } \\
\text { and large-scale studies } \\
\text { were lacking especially in } \\
\text { the area of sexual } \\
\text { function. }\end{array}$ \\
\hline
\end{tabular}




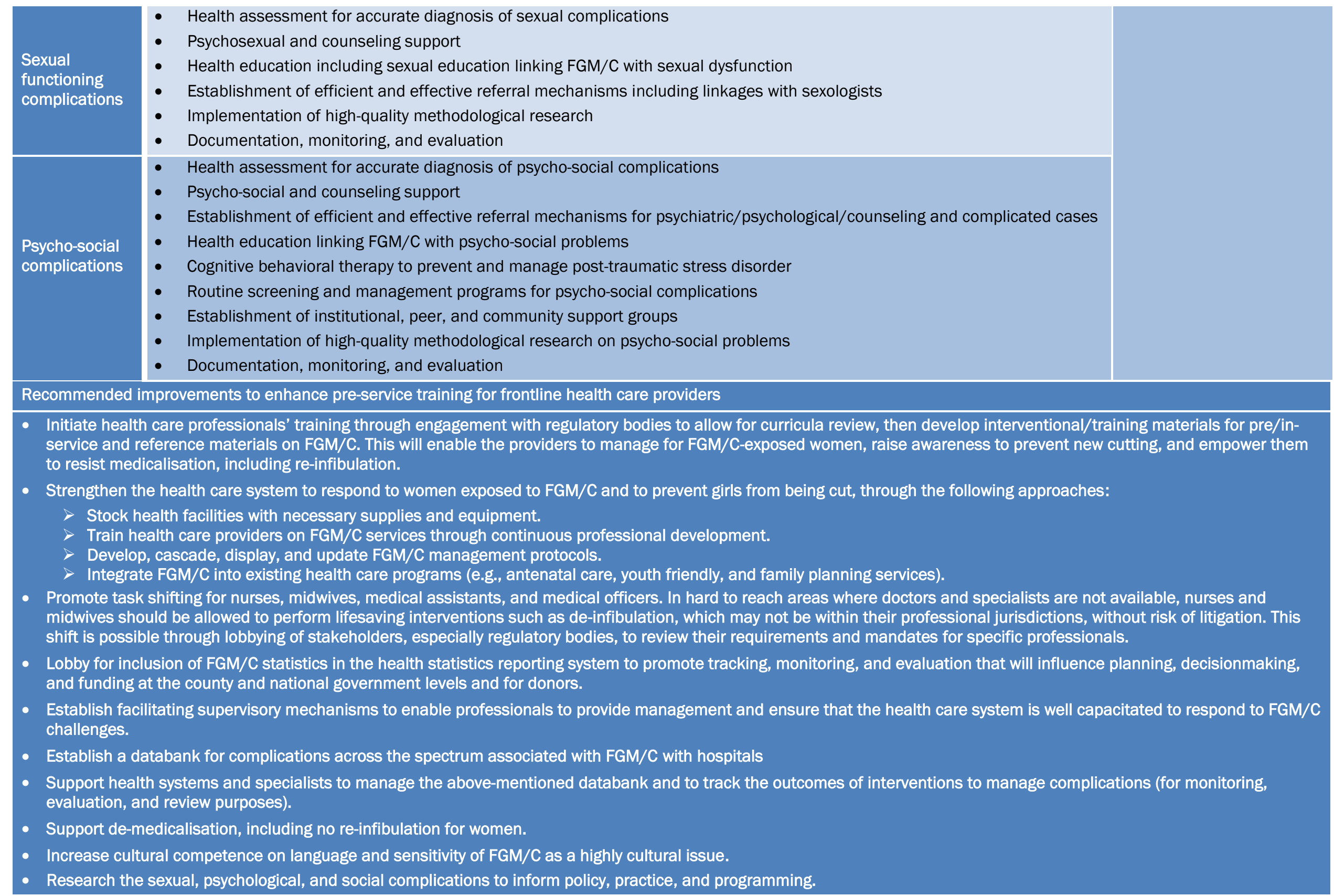




\section{CONCLUSION}

The health impacts of FGM/C have received different levels of attention, both in terms of interventions and evidence. Based on these recommendations, there is a need to communicate this evidence base to a range of stakeholders, taking into consideration that key messages are carefully crafted to ensure appropriate interpretation and guidance for action. This approach is especially important when using this evidence for medical and behaviour change interventions, given the sometimes less than successful responses to health messaging observed over the past decade. Information on the health consequences would be of most use in both hospital facilities and community settings $[56,65]$ to help in providing appropriate gynecological and obstetric services and medical treatment to women and girls immediately following cutting. This objective can be achieved through health care provider training and skills empowerment, health system strengthening, documentation and research on FGM/C issues. The health care system strengthening should therefore include establishment of an efficient and effective referral system where expertise may be lacking in order to support corrective and preventive interventions for $\mathrm{FGM} / \mathrm{C}$ in all settings.

Building the capacity of frontline health care professionals to offer curative and preventive services in FGM/C-prevalent areas in both hospital and community settings may be enhanced through lobbying for curricula review and development of training manuals and guidelines. Anchoring preventive interventions for $\mathrm{FGM} / \mathrm{C}$ to existing health care programs and sociocommunity structures, especially in high-prevalence areas, will be a promising approach to address challenges faced by cut girls and women while preventing new cutting. Furthermore, large-scale, high-quality methodological studies are recommended for specific neglected complications (sexual, psychological, and mental) associated with FGM/C to inform future preventive and corrective programs. Additionally, curative and preventive strategies for protecting girls and women from cutting need to be initiated and escalated at the socio-community level. Raising awareness of the relationship between FGM/C and health problems may increase health seeking behaviour and reporting, aiding early identification and management before complications set in.

The health impacts resulting from FGM/C place a burden on health systems, however, little is known of the costs, especially of the obstetric complications associated with FGM/C [67]. While this synthesis focused on interventions that may facilitate effective responses to women and girls exposed to the practice and promote its prevention, it is critical to also consider the cost effectiveness of the interventions for planning and programming purposes.

Furthermore, the recommended interventions for preventing and addressing $\mathrm{FGM} / \mathrm{C}$ in this synthesis not only seek to address $\mathrm{FGM} / \mathrm{C}$ as a practice rooted in gender-based discrimination and social norms but also other forms of violence against women and girls [68,69].

Women's health is a human rights issue and women's empowerment cannot be separated from issues related to women's health [70]. Moving forward, Evidence to End FGM/C: Research to Help Girls and Women Thrive plans to collaborate with policymakers, development partners, professional regulatory bodies, trainers, and other key stakeholders to review the curricula and related materials for health professionals before the much-needed training materials and guidelines for health care providers can be drafted; and to conduct new research to deepen understanding of all the health impacts of $\mathrm{FGM} / \mathrm{C}$ and their interventions. 


\section{REFERENCES}

1. Almroth, L. et al. 2001. "Male complications of female genital mutilation," Social Science \& Medicine 53(11): 1455-1460.

2. World Health Organization. 2006. "Female genital mutilation and obstetric outcome: WHO collaborative prospective study in six African countries," The Lancet 367(9525): 1835-1841.

3. Berg R. C., V. Underland, J. Odgaard-Jensen, et al. 2014. "Effects of female genital cutting on physical health outcomes: a systematic review and metaanalysis," BMJ Open 4: e006316. doi: 10.1136/ bmjopen-2014-006316.

4. World Health Organization. 2001. Female genital mutilation: integrating the prevention and the management of the health complications into the curricula of nursing and midwifery. A student's guide (pp. 144). Retrieved from http://apps.who.int/iris/bitstream/10665/66857/2/WHO_FCH_GWH_01.4.pdf

5. Kaplan et al. 2010. Manual on FGM/C for health professionals. Retrieved from http://www.mgf.uab.es/eng/resources_for_professionals/Manual_health_profesionals BR.pdf?iframe $=$ true\&width $=100 \% \&$ height $=100 \%$

6. Momoh, C. 2005. Female genital mutilation. Oxon, United Kingdom: Radcliffe Publishing Ltd

7. El Dareer, A. 1983. "Complications of female circumcision in the Sudan," Tropical Doctor 13: 131-3.

8. Ouagadjio, B. et al. 2005. Demographic and Health Survey of Chad 2004 Retrieved from https://dhsprogram.com/pubs/pdf/FR170/FR170-TD04.pdf

9. Trew, B. 2013. "Unkindest cut: 13-year-old's death shines spotlight on rise of FGM in Egypt." Retrieved May 5, 2015 (http://www.standard.co.uk/lifestyle/londonlife/unkindest-cut-13yearoldsdeath- shines-spotlight-on-rise-of-fgm-in-egypt8657104.html).

10. Migiro K. 2014. "Kenya: two to be charged with murder after Kenyan FGM victim dies." Retrieved May 5, 2015 (http://news.trust.org//item/20140423144006-gr2tf/)

11. Asuen, M. I. 1977. "Maternal septicaemia and death after circumcision," Tropical Doctor 7: 177-8.

12. Badejo, O. A. 1983. "Complications of circumcision: the Ife experience," Nigerian Med Practice 5: 103-9.

13. Osifo, D.O. and Evbuomwan, I. 2009. "Female genital mutilation among Edo people: the complications and patterns of presentation at a pediatric surgery unit, Benin City," African Journal of Reproductive Health 13: 17-25.

14. Rushwan, H. et al. 1983. "Female circumcision in the Sudan. Prevalence, complications, attitudes and change. A report of a study conducted by the faculty of medicine, University of Khartoum, Sudan (1977-1982)." Khartoum, Sudan: University of Khartoum.

15. El Defrawi, M. H. et al. 2001. "Female genital mutilation and its psychosexual impact," Journal of Sex and Marital Therapy 27: 465-73. 
16. Morrone, A., J. Hercogova, T. Lotti. 2002. "Stop female genital mutilation: appeal to the international dermatologic community," International Journal of Dermatology May; 41(5): 253-63.

17. Almroth, L. et al. 2005. "Urogenital complications among girls with genital mutilation: a hospital based study in Khartoum," African Journal of Reproductive Health 9: 118-24.

18. Browning, A., J. E. Allsworth, and L. L. Wall. 2010. "The relationship between female genital cutting and obstetric fistulae," Obstetrics and Gynecology 115: 578-83.

19. Morison, L. et al. 2001. "The long-term reproductive health consequences of female genital cutting in rural Gambia: a community-based survey," Tropical Medicine and International Health 6: 643-53.

20. Nwajei, S. D. and A. I. Otiono. 2003. "Female genital mutilation: implications for female sexuality," Women Studies International Forum 26: 575-80.

21. Okonofu, F. E. et al. 2002. "The association between female genital cutting and correlates of sexual and gynaecological morbidity in Edo State, Nigeria," British Journal of Obstretrics and Gynaecology 109: 1089-96.

22. Elnashar, A. and R. Abdelhady. 2007. "The impact of female genital cutting on health of newly married women," International Journal of Gynecology and Obstetrics 97: 238-44.

23. De Silva, S. 1989. "Obstetric sequelae of female circumcision," European Journal of Obstetrics and Gynecology and Reproductive Biology 32: 233-40.

24. Fillo, G. F. and T. Leone. 2007. "Female genital cutting, reproductive tract infections and perinatal outcome in Burkina Faso." Paper presented at the Annual Meeting of the Population Association of America, New York, NY, 29 March.

25. Jones, H. et al. 1999. "Female genital cutting practices in Burkina Faso and Mali and their negative health outcomes," Studies in Family Planning 30: 219-30.

26. Brewer, D. D. et al. 2007. "Male and female circumcision associated with prevalent HIV infection in virgins and adolescents in Kenya, Lesotho, and Tanzania," Annals of Epidemiology 17: 217-26.

27. Klouman, E., R. Manongi, and K. I. Klepp. 2005. “Self-reported and observed female genital cutting in rural Tanzania: associated demographic factors, HIV and sexually transmitted infections," Tropical Medicine and International Health 10: 105-15.

28. Maslovskaya, O., J. J. Brown, and S. S. Padmadas. 2009. "Disentangling the complex association between female genital cutting and HIV among Kenyan women," Journal of Biosocial Science 41: 815-30.

29. Yount, K. M. and B. K. Abraham. 2007. "Female genital cutting and HIV/AIDS among Kenyan women," Studies in Family Planning 38: 73-88.

30. Balk, D. 2000. "To marry and bear children? The demographic consequences of infibulation," in Shell-Duncan, B. and Y. Hernlund (eds.), Female "Circumcision" in Africa: Culture, Controversy, and Change. Boulder, CO: Lynne Rienner Publishers. 
31. Inhorn, M. C. and K. A. Buss. 1993. "Infertility, infection, and iatrogenesis in Egypt: the anthropological epidemiology of blocked tubes," Medical Anthropology Quarterly 15: 217-44.

32. Jackson, E. F. et al. 2005. "The relationship between female genital cutting and fertility in Kassena-Nankana District of Northern Ghana." Paper presented at the Annual Meeting of the Population Association of America, Philadelphia, PA, 3 May.

33. Larsen, U. and F. E. Okonofua. 2002. "Female circumcision and obstetric complications," International Journal of Gynecology and Obstetrics 77: 255-65.

34. Berg, R. C. and V. Underland. 2013. "The Obstetric Consequences of Female Genital Mutilation/Cutting: A Systematic Review and Meta-Analysis," Obstetrics and Gynecology International. Retrieved July 21, 2016 (http://dx.doi.org/10.1155/2013/496564).

35. Berg, R. C. et al. 2014. "An Updated Systematic Review and Meta-Analysis of the Obstetric Consequences of Female Genital Mutilation/Cutting," Obstetrics and Gynecology International. Retrieved July 21, 2016 (http://dx.doi.org/10.1155/2014/542859).

36. Vangen, S. et al. 2002. "Perinatal complications among ethnic Somalis in Norway," Acta Obstetricia et Gynecologica Scandinavica 81: 317-22.

37. Johnson, E. B. et al. 2005. "Increased risk of adverse pregnancy outcome among Somali immigrants in Washington state," American Journal of Obstetrics and Gynecology 193: 475-82.

38. Chibber, R., E. El-Saleh, and J. El Harmi. 2011. "Female circumcision: obstetrical and psychological sequelae continues unabated in the 21st century," Journal of MaternalFetal and Neonatal Medicine 24: 833-6.

39. Banks, E. et al. 2006. "Female genital mutilation and obstetric outcome: WHO collaborative prospective study in six African countries," Lancet 367: 1835-41.

40. Wuest, S. et al. 2009. "Effects of female genital mutilation on birth outcomes in Switzerland," BJOG 116: 1204-9.

41. Berg, R. C. and E. Denison. 2012. "Does female genital mutilation/cutting (FGM/C) affect women's sexual functioning? A systematic review of the sexual consequences of FGM/C," Sexuality Research and Social Policy 9: 41-56

42. Adinma, J. I. B. 1997. "Current status of female circumcision among Nigerian Igbos," West African Journal of Medicine 16(4), 227-31.

43. Alsibiani, S. and A. A. Rouzi. 2010. "Sexual functioning in women with female genital mutilation," Fertility and Sterility 93(3), 722-4.

44. Thabet, S. M. A. and A. S. Thabet. 2003. "Defective sexuality and female circumcision: The cause and the possible management," Journal of Obstetrics and Gynaecology Research 29(1), 12-19.

45. Shandall, A. A. 1967. "Circumcision and infibulations of females. A general consideration of the problem and a clinical study of the complications in Sudanese women," Sudan Medical Journal 5(4), 178-212. 
46. Megafu, U. 1983. "Female ritual circumcision in Africa: An investigation of the presumed benefits among Ibos of Nigeria," East African Medical Journal 60(11), 793-800.

47. Rushwan, H. 2000. "Female genital mutilation (FGM) management during pregnancy, childbirth and the postpartum period," International Journal of Gynecology and Obstetrics 70(1): 99-104.

48. Boyle, M. 2006. Wound Healing in Midwifery. Radcliffe Publishing: Oxon.

49. East, C. E. et al. 2012. "Local cooling for relieving pain from perineal trauma sustained during childbirth,” Cochrane Database of Systematic Reviews 5.

50. Gudu, W. 2014. "Acute vulvar pain in a lady with post circumcision inclusion cyst of the vulva containing stones: a case report," BMC Women's Health 14(1): 2.

51. Hamoudi, A. and M. Shier. 2010. "Late complications of childhood female genital mutilation," Journal of Obstetrics and Gynecology 32(6): 587-9

52. Asante, A., K. Omurtag, and C. Roberts. 2010. "Epidermal inclusion cyst of the clitoris 30 years after female genital mutilation," Fertility and Sterility 94(3): 1097.e1-3.

53. Jina, R. and S. Thomas. 2013. "Health consequences of sexual violence against women," Best Practice \& Research Clinical Obstetrics \& Gynaecology 27:1: 15-26.

54. World Health Organization. 2001. "Management of Pregnancy, Childbirth and Postpartum Period in the Presence of Female Genital Mutilation." Geneva: World Health Organization. Retrieved July 21, 2016 (http://apps.who.int/iris/bitstream/10665/66805/1/WHO_FCH_GWH_01.2.pdf)

55. Rouzi, A. A. et al. 2001. "The use of intrapartum defibulation in women with female genital mutilation," BJOG 108: 949-51.

56. Al-Hussaini, T. K. 2003. "Female genital cutting: types, motives and perineal damage in laboring Egyptian women," Medical Principles and Practice 12: 123-8.

57. World Health Organization. 2016. WHO Guidelines on the Management of Health Complications from Female Genital Mutilation. Geneva: World Health Organization.

58. European Parliament. 2006. "Combating violence against women. European Parliament resolution on the current situation in combating violence against women and any future action." Retrieved on July 21, 2016

(http://www.europarl.europa.eu/sides/getDoc.do?pubRef=-//EP//NONSGML+TA+P6-TA2006-0038+0+DOC+PDF+VO//EN)

59. Leye, E. and A. Sabbe. 2009. "Responding to female genital mutilation in Europe. Striking the right balance between prosecution and prevention. A review of legislation." Ghent, Belgium: International Centre for Reproductive Health, Ghent University.

60. United Nations Population Fund (UNFPA). 2015. “Demographic Perspectives on Female Genital Mutilation." Retrieved July 21, 2016 (http://www.unfpa.org/publications/demographic-perspectives-female-genitalmutilation\#sthash.kMbGmYrX.dpuf). 
61. Berg, R. C. and E. A. Denison. 2013. "Tradition in transition: Factors perpetuating and hindering the continuance of female genital mutilation/cutting (FGM/C) summarized in a systematic review," Health Care for Women International 34(10): 837-895.

62. World Health Organization. 2010. "Global Strategy to Stop Health-Care Providers from Performing Female Genital Mutilation." Retrieved July 21, 2016 (http://www.who.int/reproductivehealth/publications/fgm/rhr 10 9/en/). Geneva: World Health Organization.

63. Population Council. 2008. "Training can Enhance Providers' Management of FGM/C and Willingness to Advocate Against the Practice." Retrieved July 21, 2016 (http://pdf.usaid.gov/pdf docs/Pnadl830.pdf). New York: Population Council.

64. Morrone, A., J. Hercogova, and T. Lotti. 2002. "Stop female genital mutilation: appeal to the international dermatologic community," International Journal of Dermatology 41(5): 253-63.

65. Royal College of Obstetricians and Gynecologists. 2009. "Female genital mutilation and its management." Retrieved July 21, 2016 (https://www.rcog.org.uk/en/guidelinesresearch-services/guidelines/gtg53/).

66. Makhlouf Obermeyer, C. 2005. "The consequences of female circumcision for health and sexuality: an update on the evidence," Culture, Health \& Sexuality 7(5): 443-61.

67. Adam, T. et al. 2010. " Estimating the obstetric costs of female genital mutilation in six African countries," Bull World Health Organ 2010;88: 281-288.

doi:10.2471/BLT.09.06480.

68. UN Women. Focusing on Prevention to Stop the Violence. Retrieved August 10, 2016 (http://www.unwomen.org/en/what-we-do/ending-violence-against-women/prevention).

69. Remme, M., C. Michaels-lbokwe, and C. Watts. 2014. "Approaches to assess value for money and scale up of violence against women and girls prevention: A summary of the evidence." Retrieved August 10, 2016 (http://r4d.dfid.gov.uk/pdf/outputs/VAWG/What_Works_Inception_Report_June_2014 AnnexK Summary Scalability Final.pdf)

70. World Health Organization, Regional Office for Africa. 2012. Addressing the Challenge of Women's Health in Africa: A Summary of the Report of the Commission on Women's Health in the African Region. Brazzaville, Republic of Congo: World Health Organization, Regional Office for Africa. Retrieved August 11, 2016 (http://www.afro.who.int/en/clusters-a-programmes/frh/gender-womens-health-aageing/highlights/3741-addressing-the-challenge-of-womens-health-in-africa.html). 